\title{
The Determinant of Banking Efficiency (Data Envelopment Analysis Based on Intermediation Approach)
}

Nabila Zahra*, Darwanto
Faculty of Economy and Business, Diponegoro University
$*$ Corresponding Author: nabilazhr95@gmail.com

Recieved: February 2018 | Revised July 2018 | Accepted: May 2019

\begin{abstract}
This research aims at analyzing the level of efficiency with intermediation approach and determinant of efficiency of Bank Pembangunan Daerah (BPD). Efficiency is measured using the Data Envelopment Analysis (DEA) method based on the intermediation approach. This research contribute on modelling of determinant of efficiency of Bank Pembangunan Daerah (BPD) using intermediation approach. The object of this research is $26 \mathrm{BPD}(\mathrm{s})$. Furthermore, the determinant of efficiency of $\mathrm{BPD}$ is analyzed using the Tobit regression. The level of efficiency is the dependent variable. Meanwhile, the independent variables used are CAR, LDR, NPL, NIM, ROA, Inflation, Economic Growth, and Interest Rate. The research results show that BPD has a different efficiency level average (high, sufficient, moderate, and low efficiency level average). This is due to the use of inputs that have an impact on the optimal output maximization. CAR and LDR have the significant and positive effects on the efficiency of BPD. Interest rate and inflation have the significant and negative effects on the efficiency of BPD. Meanwhile, NPL, NIM, ROA and Economic Growth have no effects on the efficiency of BPD. This results is expected to contribute in identifying any factor affecting the efficiency of BPD, both the internal and macro economy, and also to be the stimulus for the development of health measuring instrument of BPD in which efficiency reflects the quality of risk management on the intermediary activity of BPD.
\end{abstract}

Keywords: technical efficiency, Bank Pembangunan Daerah, data envelopment analysis (DEA), Tobit JEL Classification: C1; E44; G20; N10; P24

How to Cite: Zahra, N., \& Darwanto, D. (2019). The Determinant of Banking Efficiency (Data Envelopment Analysis Based on Intermediation Approach). Jurnal Ekonomi Pembangunan: Kajian Masalah Ekonomi dan Pembangunan, 20(1). doi:https://doi.org/10.23917/jep.v20i1.5799

DOI: https://doi.org/10.23917/jep.v20i1.5799

\section{Introduction}

Finance institutions especially banking have a very important role in the economy that is as an intermediary institution or intermediation (Kurnia, 2004). Based on the Acts No. 10 in 1998, a bank has a role as an intermediary institution or intermediation to improve people's standard of living. The study of Finance Stability in March 2016 shows that banks have a total asset of $74.40 \%$. Banking has a big role on it, so it is demanded to work stably and efficiently
BPD is a part of the national banking industries. According to the Acts No. 13 in 1962, BPD is a bank built in the first-level autonomous region, which is intended to provide the financing for the implementation of the regional development planning in the framework of the Universal National Development of Planning.

BPD has a strategic role in encouraging the regional economy in the form of the provision of financial service products in line with each region's characteristics and needs. Another role of 
BPD in the regional development is also shown by the local government's trust in BPD as the main collector of the government funds, especially those distributed by the local government. The big role of BPD in the regional economy management becomes the fundamental factor of its role as the agent of regional development. BPD has the sustainable improving development, which can be seen from the development of the total asset, the collected third party funds (DPK), and the distributed total credit. This can be seen in the following figure.

Figure 1 indicates that DPK on BPD keeps showing improvement, which makes BPD have excess funds to distribute the credits, so the total credit of BPD keeps showing the improving trend. However, the credit of BPD is dominated by the consumption credit. Based on the Indonesian
Banking Statistics, the consumption credit dominates with $70.79 \%$ or 252,882 billion rupiahs (per December 2016), and then it is followed by the working capital credit and investment credit with $18.21 \%$ (65,060 billion rupiahs) and $10.99 \%$ (39,284 billion rupiahs).

Abidin and Endri (2010) stated that BPD must show its optimum performance in order to support the regional development financing and strengthen its function as the intermediation institution. Efficiency is one indicator of banking performance measure. Efficiency for a bank or a banking industry as a whole is the most important aspect to realize the healthy and sustainable financial performance. In general, the financial ratio is used to measure a bank performance in Indonesia, as shown in Table 1.

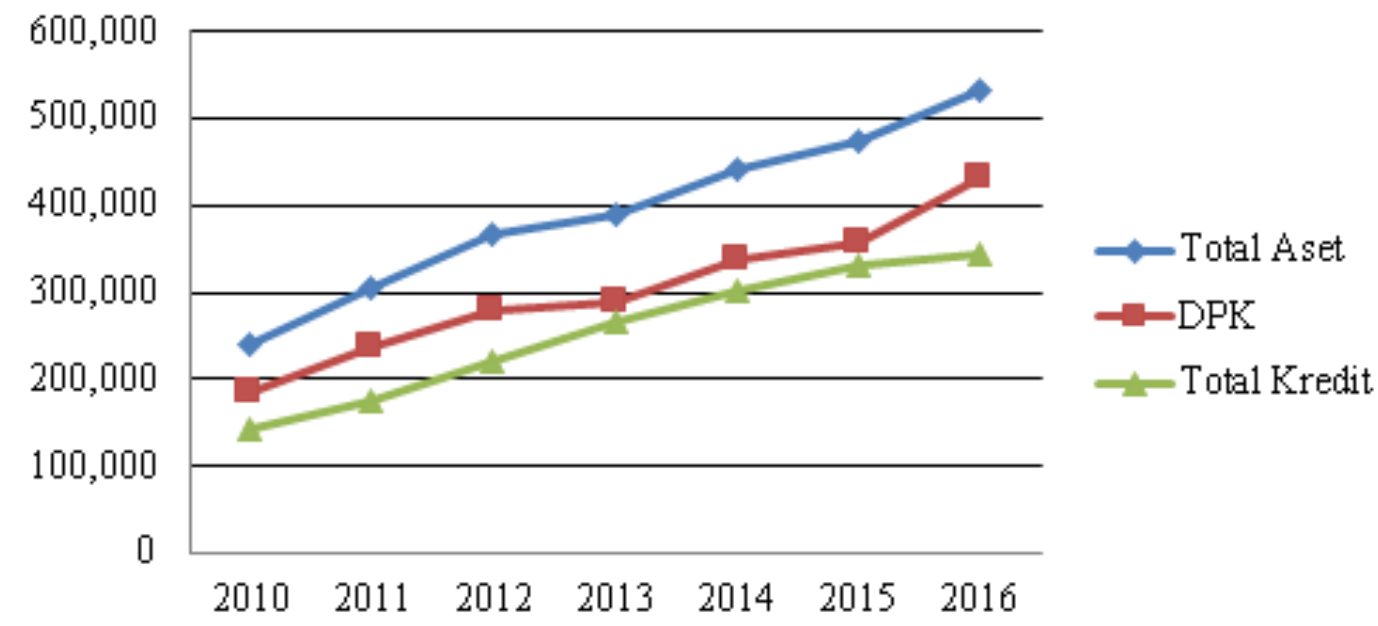

Source: Indonesian Banking Statistics 2010 - 2016, processed

Figure 1. Development of Total Asset, DPK, and Total Credit of BPD in 2010- 2016

Table 1. Financial Ratio of BPD in 2010- 2016

\begin{tabular}{lrrrrrrr}
\hline \multicolumn{2}{c}{ Indicator } & \multicolumn{1}{c}{$\mathbf{2 0 1 0}$} & \multicolumn{1}{c}{$\mathbf{2 0 1 1}$} & \multicolumn{1}{c}{$\mathbf{2 0 1 2}$} & $\mathbf{2 0 1 3}$ & $\mathbf{2 0 1 4}$ & \multicolumn{2}{c}{$\mathbf{2 0 1 5}$} & $\mathbf{2 0 1 6}$ \\
\hline LDR (\%) & 78.26 & 74.74 & 78.57 & 92.34 & 89.73 & 92.19 & 93.65 \\
NPL (\%) & 2.06 & 1.75 & 2.3 & 2.81 & 3.45 & 3.67 & 3.84 \\
NIM (\%) & 8.74 & 8.1 & 6.7 & 7.04 & 6.65 & 6.66 & 7.07 \\
CAR (\%) & 16.68 & 14.33 & 18.02 & 17.8 & 17.79 & 20.61 & 21.69 \\
ROA (\%) & 3.82 & 3.36 & 2.9 & 3.18 & 2.68 & 2.4 & 2.58 \\
BOPO (\%) & 77.65 & 79.14 & 75.29 & 73.49 & 78.08 & 79.57 & 78.08 \\
\hline
\end{tabular}

Source: Indonesian Banking Statistics 2010 - 2016, processed 
Based on the financial ratio, the liquidity of BPD is at the tight level because the value of LDR BPD was over $92 \%$ or $93.65 \%$ per December 2016. LDR BPD was improving from 2014 to 2016. In 2012 it was $89.73 \%$, improved to be $92.19 \%$ in the next year, and became $93.65 \%$ in 2016. The improvement of LDR is caused by the improvement of credit distribution. The implementation of intermediary function of BPD is along with the prudential principle and the good risk-management practice, so that BPD still has low non-performing loans. The value of NPL BPD was $3.84 \%$ per December 2016, which was still under threshold 5\%. Although it is relatively low, NPL BPD was improving every year from 2011 to 2016. The low non-performing loans give impact on the profit of BPD that was $2.8 \%$ per December 2016, as presented by ROA. Based on the regulation of Bank Indonesia, any bank having ROA over $1.5 \%$ is included in healthy banks. NIM BPD is relatively high, which shows that the bank intermediation cost becomes expensive. It makes people reluctant to have loans on BPD so that BPD becomes inefficient. BOPO BPD shows that BPD has not been efficient yet with $78.08 \%$ per December 2016. Based on the regulation of Bank Indonesia, the ideal BOPO is $60 \%-70 \%$. Therefore, $\mathrm{BPD}$ is demanded to press its operational cost.

Based on the measurement of financial ratio, BPD has not been efficient yet, which can be seen from the indicator of the increasing NIM and BOPO BPD. The performance measurement based on the ratio is not able to directly find out how the efficient level a bank can reach (Utami and Sufian, 2011). One method often used to analyze the bank efficiency is the non-parametric method of data envelopment analysis (DEA). The banking efficiency analysis based on DEA method will find clearer description about any factor causing a bank inefficient. A bank is called efficient if it is able to produce more output with the same input or able to use less input than another bank with the same output (Pambuko, 2016).

Berger and Master (1997) stated that the banking industrial efficiency can be seen from the micro or micro point of view. Based on the micro point of view, to be able to survive and develop, a bank should be efficient in its operational activities in order to face more fierce competition. Inefficient banks probably will leave the market due to the inability to compete with their competitors, whether in prices or in quality of products and services. Meanwhile, from the macro point of view, an efficient banking industry is able to affect the financial intermediation cost and the financial system stability as a whole, which is due to the strategic role of banking as the intermediation institution and the financial service producer. The higher the efficient level is, the better the banking performance can allocate the financial resources, and finally it will improve the investment activities and the economic growth.

The efficient level of a bank depends much on various factors, both internal and external factors. As an intermediation institution in the financial market, the operational activities of BPD are influenced by its own specification and the economic macro condition. Most previous researches have been conducted to analyze the banking efficiency and its determinant, either in Indonesia or in other countries. However, the empirical research indicates the various and inconsistent results. There is no generalization.

CAR is considered to be one factor that affects the efficiency level of a bank. CAR shows the bank security level. Pambuko (2016) in his research found that CAR has the positive effect on efficiency; the greater the bank financing ability is in taking risks, the more efficient the bank will be. It is in line with the findings of Pancurova and Lyocsa (2013) and Akmal and Saleem (2008). However, Adjei-Frimpong, Gan, and $\mathrm{Hu}$ (2014) found that CAR has the negative effects on efficiency.

LDR described the bank ability to pay back the withdrawal conducted by the depositor costumers by counting on the credits given as the source of liquidity (Mandala \& Widodo, 2016). Jaelani (2015) stated that the higher the ratio of LDR is, the more efficient the process of finance intermediation will be provided by the bank. 
Pambuko (2016), Sufian dan Kamarudin (2016), Muljawan, Hafidz, Astuti, and Oktapiani (2014), and Jaelani (2015) showed that LDR has positive effects on the bank efficiency.

NPL shows the credit quality indicator. The high NPL indicates the bad quality of credit because the amount of non-performing loans grow more and more, while the low NPL indicates the good credit quality. NPL increase will make the bank inefficient because of the decreasing income produced. Garza-García (2012) and Andries (2010) found the negative effect of NPL on the bank efficiency. This is not in line with Jaelani (2015) and Pambuko (2016) who found that NPL has the positive effect on the efficiency level. Adjei-Frimpong et al. (2014) in his research found that NPL has no effects on efficiency.

Net Interest Margin (NIM) is a measure of difference between the interest income produced and the cost the bank delivered for the funding that is divided by the total asset (Jaelani, 2015). Stiglitz and Weiss stated that the high NIM is the result of asymmetric information and market interaction to the transaction cost that cause inefficiency (Mandala \& Widodo, 2016). It can be concluded that the lower NIM is, the better the bank efficiency level will be. Garza-García (2012), Hassan and Sanchez (2007) and Jaelani (2015) found that there is a negative relationship between NIM and the bank efficiency level. It is different from the research conducted by Muljawan et al. (2014), which found that there is a positive relationship between NIM and the bank efficiency level.

ROA reflects the bank managing ability to produce the profits by using the finance assets provided efficiently (Jaelani, 2015), so that there is a positive relationship between ROA and efficiency. Adjei-Frimpong et al. (2014), Hassan and Sanchez (2007), and Pambuko (2016) found the positive relationship between ROA and efficiency. Different from the above research, Muljawan et al. (2014) found that ROA has no significant impact on efficiency.

When the high inflation level may cause the decrease in people's ability to save their funds in a bank (Jaelani, 2015), Adjei-Frimpong et al. (2014) stated that the inflation increase will cause the increase in the non-performing loans that may decrease the bank efficiency. Hassan and Sanchez (2007), Pancurova and Lyocsa (2013), Garza-García (2012) show that inflation has a negative effect on the bank efficiency. It is different from the findings of Adjei-Frimpong et al. (2014), Jaelani (2015), and Endri (2015), showing that inflation has a positive effect on the bank efficiency. Akmal and Saleem (2008) stated that inflation is not significant for the efficiency.

Garza-García (2012) thought that if the economic growth affects positively on the efficiency, the demand on financial service will tend to grow in line with the economic development. GarzaGarcía (2012), Hassan and Sanchez (2007), and Pancurova and Lyocsa (2013) found evidence that there is a positive effect of the economic growth on the bank efficiency. It is different from Akmal and Saleem (2008), Adjei-Frimpong et al.(2014), and Jaelani (2015) who found evidence that the economic growth has negative effects on the bank efficiency.

The high interest rate in a bank on one side is interesting for the costumers to save their funds to find the exact profit. On the other side, the credit distribution becomes decreasing so that the bank is burdened by the high operational cost in running its intermediation function and it may cause the bank inefficient (Endri, 2015). Endri (2015) and Hassan and Sanchez (2007) found that the interest rate has negative effects on the bank efficiency. However, it is different from Garza-García (2012) who found evidence that the interest rate is not significant for the bank efficiency.

Based on the description above, it can be concluded that there is still a research room based on the previous research results about the efficiency determinant. Therefore, the researcher wishes to develop further the analysis of determinant of banking efficiency. This research aims at examining the efficiency level and analyzing the determinant of efficiency level of Bank Pembangunan Daerah in Indonesia during 
the period of 2012-2016. This finding is expected to contribute in identifying any factor affecting the efficiency of BPD, both the internal and macro economy, and also to be the stimulus for the development of health measuring instrument of BPD in which efficiency reflects the quality of risk management on the intermediary activity of BPD.

\section{Research Method}

\subsection{Object and Variables of Research}

The object of research of this study includes 26 BPD in Indonesia during the period of 20122016. The data used is secondary data in the form of three-monthly data from the Financial Service Authorities (OJK), Bank Indonesia, and Central Bureau of Statistics (BPS).

The analysis of the efficiency level of BPD in Indonesia in this study is conducted in two steps. First is Data Envelopment Analysis (DEA) with the intermediation approach to measure the efficiency level. The input variables used in this research include the Third Party Funds (DPK), the working cost, and the fixed assets. Whereas those used for the output variables are the total credit, the interest income, and the operational income except the interest. Second, the score of DEA measuring result will be used as the dependent variable analyzed using the Tobit model to analyze the determinant of efficiency level of BPD in Indonesia. The independent variables which effects will be examined are CAR, LDR, NPL, NIM, ROA, the inflation, the economic growth, and the interest rate.

\subsection{Data Analysis Method}

\subsubsection{Data Envelopment Analysis (DEA)}

Data Envelopment Analysis (DEA) is a mathematic program with non-parametric approach to estimate the frontier (Coelli, Prasada, Bettese, \& O'Donnell, 2005). The aim of DEA method is to measure the efficiency level of the decision-making unit (DMU) relatively on the similar bank when all units are at or under their frontier efficient curves. This method is used to evaluate the relative efficiency of several objects (Abidin \& Endri, 2010).

The efficiency score for each unit is relative depending on the efficiency level of the other units in the sample. Each unit in the sample is considered to have non-negative efficiency level, and the rate is between 0 and 1 with the provision that 1 indicates the perfect efficiency. Afterwards, the units having rate 1 are used in making envelope for the efficiency frontier, while the other units in the envelope indicate the inefficiency level. The following is the efficiency measurement formula (Abidin \& Endri, 2010):

$$
\text { Efficiency }=\frac{\sum_{k=1}^{n} \mu_{k} y_{r j}}{\sum_{i=1}^{m} v_{i} x_{i j}}
$$

where $\mathrm{k}=$ the bank to be evaluated; $\mathrm{m}=$ number of inputs; $\mathrm{n}=$ number of outputs; $\mathrm{x} \_\mathrm{ij}=$ input value to-i bank j; $y_{-}$ij = value of output to bank $j$; $\mu \_k$ = weight of bank $\mathrm{k}$ for the evaluated bank; $\mathrm{v} \_\mathrm{i}$ = weight of bank $\mathrm{j}$ for calculated bank

There are three approaches in defining the relationship of input and output used in the efficiency measurement as follows: (1) the production approach; (2) the asset approach; (3) the intermediation approach. The production approach focuses on the bank activities by collecting the funds from the people in the form of savings. The intermediation approach focuses on the bank activities in running the intermediation function to distribute the savings in the form of credits. This approach describes the financial institution as intermediary. The asset approach focuses on the asset quality required to maintain in order to increase the bank performance. This approach describes the primary function of the financial institution as the loan creator. As the loan creator, this approach is almost similar to the intermediation approach, but the output is defined in the form of assets. This research used the intermediation approach. Hadad, Santoso, Ilyas, and Mardanugraha (2003) stated that the banking has a task to collect the funds from 
people and to redistribute them in the form of credit; this is the special role for the banking as the intermediation institution.

DEA method was introduced first by Charnes, Cooper and Rhodes in 1978 that assumes a model which ratio of addition of input and output is similar (constant return to scale or CRS). CRS assumption will fit if all DMU operate on the optimum scale. CCR model later was developed by Banker, Charnes and Cooper in 1984, or recognized as BCC model. BCC model assumes that a company is not operating or has not operated yet on the optimum scale. Competition, government regulation, and financial obstacles may cause the company not operate on its optimum scale (Coelli et al., 2005).

Constant Return to Scale (CRS) model assumes that ratio of addition of input and output is similar or constant. If there is an additional input of $\mathrm{x}$ times, the output will also increase as $\mathrm{x}$ times. Another assumption used in this model is that each DMU operates on the optimum scale. Whereas, Variable Return to Scale (VRS) model assumes that if there is an additional input as $\mathrm{x}$ times, the output will increase less or more than $\mathrm{x}$ times. The score of efficiency of DEA with the CRS assumption is found through a notation assuming that the data consisting of $\mathrm{N}$ input and $\mathrm{M}$ output for each I company. The I company is indicated by vector column $x_{i}$ and $q_{i}$. $\mathrm{X}$ is matrix input $\mathrm{N}$ x I and $\mathrm{Q}$ is matrix output $\mathrm{Mx} \mathrm{I}$ to represent the data of the whole company (Coelli et al., 2005).

The ratio measurement for all output and input in each company is indicated by $u^{\prime} q_{i} / v^{\prime} x_{i}$ where $\mathrm{u}$ is $\mathrm{M} x \mathrm{I}$ vector of output weight and $\mathrm{v}$ is $\mathrm{N} x$ I vector of input weight. The optimal weight is found by searching for solution of system of equation as follows (Coelli et al., 2005) :

$$
\begin{aligned}
& \max _{u, v}\left(u^{\prime} q_{i} / v^{\prime} x_{i}\right) \\
& \text { st' } \quad u^{\prime} q_{j} / v^{\prime} x_{j} \leq 1, \quad j=1,2, \ldots, I \\
& u, v \geq 0
\end{aligned}
$$

The obstacle in the efficiency measurement is $\leq 1$. Preventing the presence of the number of infinity is required to add the obstacle $=1$, which is indicated by:

$$
\begin{aligned}
& \max _{\mu, v}\left(\mu^{\prime} q_{i}\right), \\
& \text { St } \quad v^{\prime} x_{i}=1, \\
& \mu^{\prime} q_{j}-v^{\prime} x_{j} \leq 0, j=1,2, \ldots, I \\
& \mu, v \geq 0
\end{aligned}
$$

Using the linear program dual, the above equation can be derived as follows:

$\min \theta, \lambda \theta$

$$
\begin{array}{r}
\text { st }-\mathrm{qi}+\mathrm{Q} \lambda \geq 0, \\
\theta x i-\mathrm{X} \lambda \geq 0, \\
\lambda \geq 0
\end{array}
$$

where $\theta$ is the scale of $\lambda$ is $1 \times$ I vector constant. The rate of $\theta$ is the score of efficiency for the I company that is $\theta \leq 1$. The score of efficiency of DEA assuming VRS is found by adding $\lambda=1$ (where I1 is $1 \mathrm{x}$ I vector one) into the equation as follows:

$$
\begin{array}{r}
\min \theta, \lambda \theta \\
\text { st }-\mathrm{q} i+\mathrm{Q} \lambda \geq 0, \\
\theta \mathrm{xi}-\mathrm{X} \lambda \geq 0, \\
\lambda=1 \\
\lambda \geq 0
\end{array}
$$

This research will use a model with VRS assumption or called BCC model. It is because the fund distribution in the banking may not be optimally conducted due to the imperfect competition, the financial obstacles, and the other external factors. This research also uses efficiency with an approach oriented in output. It is because the aim of DMU is to find the maximum profit by optimizing the owned resources.

\subsubsection{Tobit Model}

Tobit regression is used to analyze the determinant of the efficiency level of BPD in Indonesia. The efficiency level is found previously at the first stage using DEA method. The use of 
Tobit regression model is because the dependent variable value is censored or limited, while the independent variable value is non-censored or unlimited. If it uses the multiple regressions using the Ordinary Least Squares (OLS) method, the result will bias and not consistent, because the big amount of the dependent variables $(\mathrm{Y})$ with zero value makes it difficult to conduct transformation to handle the problem of assumption breaking that is the normality assumption, so that this linier regression cannot be applied. The Tobit standard model can be defined for the I bank as follows (Endri, 2015) :
$\mathrm{yi}^{*}=B x i i^{\prime}+\sigma \varepsilon \mathrm{i}$

where:

$y i=y i *$ if $y i^{*}>0$

$y i=0$ if $y i^{*} \leq 0$

In Tobit model there is additional information of scale coefficient that is the scale factor that will be estimated $\sigma$. This scale factor can be used to estimate the standard of deviation from the residual. The likelihood function is maximized to estimate the parameter $B$ and $\sigma$ based on the observation of and.
$\mathrm{L}=\Pi_{\mathrm{yi}=0}\left(1-\mathrm{F}_{\mathrm{i}}\right) \Pi_{\mathrm{yi}>0} \frac{1}{\sqrt{2 \pi \sigma^{2}}} \mathrm{e}^{-\left(\mathrm{y}_{\mathrm{i}}-\Sigma \beta_{\mathrm{k}} \mathrm{x}_{\mathrm{k}}\right)^{2} /\left(2 \sigma^{2}\right)}$

di mana

$$
\mathrm{F}_{\mathrm{i}}=\frac{1}{\sqrt{2 \pi \sigma^{2}}} \int_{-\infty}^{\Sigma \beta_{\mathrm{k}} \mathrm{x}_{\mathrm{k}}} \mathrm{e}^{-\mathrm{t}^{2} /\left(2 \sigma^{2}\right)} \mathrm{dt}
$$

The Tobit regression equation in this research is as follows:

EFFit $=c+\beta 1$ CARit $+\beta 2$ LDRit $+\beta 3$ NPLit + $\beta 4$ NIMit $+\beta 5$ ROAit $+\beta 6$ INFit $+\beta 7$ PDRBit + $\beta 8$ SBit + Eit

$\mathrm{FF}=$ score of efficiency; $\mathrm{CAR}=$ Capital Adequacy Ratio; LDR = Loan to Deposit Ratio;NPL $=$ Non Performing Loan; NIM $=$ Net Interest Margin; ROA $=$ Return On Assets; INF = inflation; $\mathrm{PDB}=$ economic growth; $\mathrm{SB}=$ interest rate $; \mathrm{c}=$ constanta $($ intercept $)$

\subsubsection{Statistic Test}

Mason and Lind (1996) stated that statistic test is a value determined based on the information and sample used to determine whether it will receive or refuse the hypothesis. One of the statistic tests is z-statistic test. It is a statistic test which hypothesis testing is closed to the normal distribution. The $\mathrm{z}$ test is used to examine the hypothesis partially or individually, whether the independent variables have effects in explaining the dependent variables partially. In examining the hypothesis, the $\mathrm{z}$ test is calculated by:

$\mathrm{Z}=\frac{\bar{x}-\mu}{\sigma / \sqrt{n}}$

The $\mathrm{z}$ value is based on the sampling distribution from $\bar{X}$, which has the normal distribution with the calculation average $(\mu \underline{\bar{x}}$ ) equals to $\mu$, and the standard deviation $\sigma \bar{x}$, which equals to $\sigma$. with the following hypothesis:

$\mathrm{H}_{0}$ : the independent variables have no significant positive / negative effects on the dependent variables.

$\mathrm{H}_{0}$ : the independent variabels have significant positive / negative effects on the dependent variabels.

Thus, the statistic test can be conducted as follows:

If $\left|Z_{\text {hit }}\right| \leq\left|Z_{\text {table }}\right|, H_{0}$ is not refused.

If $\left|Z_{\text {hit }}\right| \leq\left|Z_{\text {table }}\right|, H_{0}$ is refused. 


\subsubsection{Likelihood Ratio Test}

Hosmer and Lemeshow (2000) stated that Likelihood Ratio (LR) test is used to examine the model significance as a whole. The LR test follows the distribution of chi squares (). The LR test will find a statistic test as follows:

$\mathrm{LR}=2(\mathrm{ULLF}-\mathrm{RLLF})$

where:

ULLF $=$ Unrestricted Log likelihood Function

RLLF $=$ Restricted Log likelihood Function

Using the degree of conviction $95 \%(\alpha=0.05)$, with the degree of freedom (df) $=\mathrm{k}=8$ (because $\mathrm{n}>100$ ), it finds $=15.507$, with the following hypothesis:
$\mathrm{H}_{0}: B 1=B 2=\ldots=B \mathrm{i}=0$

$\mathrm{H}_{1}$ : at least there is one free variable $\neq 0$

Afterwards, Hosmer and Lemeshow (2000) explained that the statistic test can be conducted as follows :

If $\mathrm{LR} \leq \chi_{\text {table }}^{2}, \mathrm{H}_{0}$ is not refused, $B_{1}=B_{2}=\ldots=B_{\mathrm{i}}=0$

If $\mathrm{LR}>\chi_{\text {table }}^{2}, \mathrm{H}_{1}$ is refused, at least there is one free variable $\neq 0$

\section{Result And Discussion}

The calculation result of efficiency of Bank Pembangunan Daerah using the Data Envelopment Analysis in the period of 2012Q12016Q2 is presented in the Table 2.

Table 2. Classification of Efficiency of BPD based on the average per BPD

\begin{tabular}{cccccc}
\hline \multicolumn{2}{c}{ Percentage Interval } & $\begin{array}{c}\text { Criteria of } \\
\text { Efficiency }\end{array}$ & Frequency & Percentage \\
\hline $94.8 \%$ & $<$ Score $\leq$ & $100.0 \%$ & Very High & 16 & $61.5 \%$ \\
$89.7 \%$ & $<$ Score $\leq$ & $94.8 \%$ & Sufficient & 3 & $11.5 \%$ \\
$84.5 \%$ & $<$ Score $\leq$ & $89.7 \%$ & Moderate & 4 & $15.4 \%$ \\
$79.3 \%$ & $<$ Score $\leq$ & $84.5 \%$ & Low & 3 & $11.5 \%$ \\
\hline \multicolumn{2}{c}{ Amount } & & $\mathbf{2 6}$ & $\mathbf{1 0 0} \%$ \\
\hline
\end{tabular}

Source : processed data, 2017.

Table 3. Scenario of Efficiency Improvement in BPD DIY

\begin{tabular}{lrrrr}
\hline \multicolumn{1}{c}{ Variable } & \multicolumn{1}{c}{$\begin{array}{c}\text { Original } \\
\text { Value }\end{array}$} & $\begin{array}{c}\text { Radial } \\
\text { Movement }\end{array}$ & $\begin{array}{c}\text { Slack } \\
\text { Movement }\end{array}$ & $\begin{array}{c}\text { Projected } \\
\text { Value }\end{array}$ \\
\hline Output : & & & & \\
Total Credit & $3,175,008.00$ & $1,073,431.90$ & 0.00 & $4,248,439.90$ \\
Interest Income & $141,355.00$ & $47,790.42$ & $20,931.08$ & $210,076.50$ \\
Non-interest Income & $5,553.00$ & $1,877.40$ & $14,397.43$ & $21,827.84$ \\
Input: & & & & \\
DPK & $5,140,607.00$ & 0.00 & 0.00 & $5,140,607.00$ \\
Worker Weight & $41,385.00$ & 0.00 & 0.00 & $41,385.00$ \\
Fixed Assets & $207,366.00$ & 0.00 & $-87,605.65$ & $119,760.35$ \\
\hline
\end{tabular}

Source : processed data, 2017. 

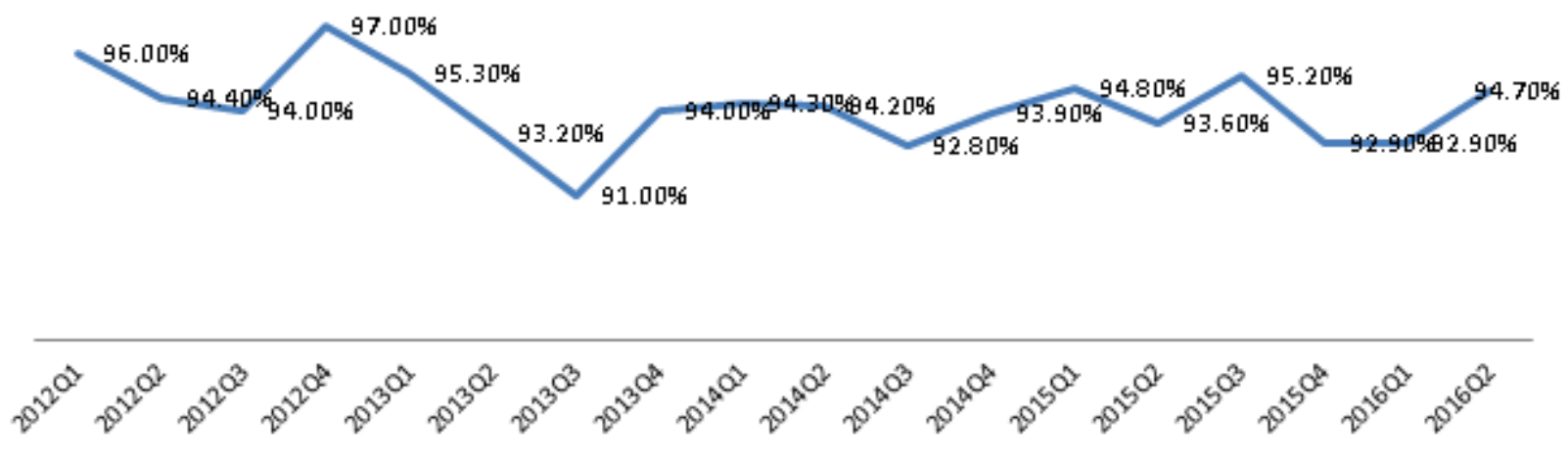

Figure 2. Average of Efficiency of All BPD in 2012Q1- 2016Q2

Source : processed data, 2017.

Table 4. Result of Efficiency Regression

\begin{tabular}{|c|c|c|}
\hline Variable & Coefficient & z-Statistic \\
\hline $\mathrm{C}$ & 0.879 & 21.392 \\
\hline CAR & 0.351 & 3.780 \\
\hline LDR & 0.092 & 3.367 \\
\hline NPL & 0.346 & 1.784 \\
\hline NIM & 0.011 & 0.145 \\
\hline ROA & 0.080 & 0.198 \\
\hline Inflation & -0.064 & -2.389 \\
\hline EconomicGrowth & 0.005 & 0.530 \\
\hline Interest Rate & -1.223 & -2.315 \\
\hline Restricted Log likelihood & & 490.263 \\
\hline Unrestricted Log likelihood & & 507.348 \\
\hline
\end{tabular}

Source : processed data, 2017.

Table 2 shows that there are four classifications of the efficiency level of BPD as follows: BPD with the efficiency level average very high, sufficient, moderate, and low. BPD with very high efficiency level is $61.5 \%$ or 16 banks. BPD Bali, BPD West Java and Banten, and BPD Jambi are those having $100 \%$ of efficiency level during the period of 2012Q1-2016Q2. BPD included in the sufficient efficiency level average is $11.5 \%$ or three banks those are BPD NTB, BPD Southeast Sulawesi, and BPD West Sumatera. BPD Aceh, BPD Central Kalimantan, BPD Maluku, and BPD Papua are those having the moderate efficiency level average. There are three BPD that have the low efficiency level average those are BPD
Yogyakarta, BPD West Kalimantan, and BPD North Sumatera. BPD with the low efficiency level average are indicated as those having not been efficient yet in utilizing all potential abilities they own to be able to produce the maximum output.

BPD Yogyakarta is BPD that has the lowest efficiency level average of $79.31 \%$ during the period of research in 2012Q1-2016Q2. To improve the efficiency, BPD Yogyakarta should conduct what have been shown in table 3 . It should increase the total credit to be $4,248,438.90$ million rupiahs, increase the interest income to be 210,076.50 million rupiahs, and increase the noninterest income to be 21,827.84 million rupiahs. Besides, BPD Yogyakarta also should decrease 
the input variable that is the fixed assets to be $119,760.35$ rupiahs.

Figure 2 shows that the average of efficiency of all Bank Pembangunan Daerah (BPD) had not reached $100 \%$ of the optimal efficiency level during the period of 2012Q1-2016Q2 where the efficiency score fluctuated. In 2012Q4, BPD has its highest efficiency level average that is 97\%, while in 2013Q3 it has its lowest efficiency level average that is $91 \%$. This shows that bank BPD has not been efficient yet in its operational activities in utilizing all its potential abilities it owns to produce the maximum output.

From the estimation result, CAR variable has positive and significant effects on the efficiency of BPD, because the z-statistic value of 3.780 is greater than the $\mathrm{z}$-table value of 1.960 . If CAR increases of $1 \%$ and the other variables are considered to be constant, then efficiency of BPD will increase of $0.879 \%$. It is in accordance with the theory. According to Pambuko (2016), the greater the bank financing ability is in covering the risks, the more efficient the bank will be. Other researches find the positive relationship between CAR and efficiency such as Pancurova and Lyocsa (2013) on the banking cases in 11 countries of CEE in 2005-2008, Akmal and Saleem (2008) on the banking cases in Pakistan in 19952005, Pambuko (2016) on the syariah bank cases in Indonesia in 2010-2013, and Jaelani (2015) on the general bank cases in Indonesia in 2002-2013.

The LDR variable has significant and positive effects on the efficiency of BPD, because the $z$-statistic value of 3.367 is greater than the $z$-table value of 1.960 . If LDR increases of $1 \%$ and the other variables are considered to be constant, the efficiency of BPD will increase of $0,092 \%$. It is in accordance with the theory. According to Jaelani (2015), the higher the LDR is, the more efficient the process of financial intermediation provided by the bank will be and the greater the portion of DPL allocated for the financing / credit will be, so that these will make the bank more efficient. It is in accordance with the researches of Pambuko (2016), Sufian and Kamarudin (2016), Muljawan et al. (2014), and Jaelani (2015), which found there is a positive relationship between LDR and efficiency.

The NPL variable is not significant for the efficiency of BPD, because the z-statistic value of 1.784 is less than the z-table value of 1.960 . This research is in line with Adjei-Frimpong et al. (2014) who found that ratio variable of the allowance for the credit loss is not the important factor in affecting the bank efficiency in Ghama. The NIM variable is not significant for the efficiency of BPD, or in other words, NIM BPD has no real contribution on the efficiency attainment of BPD, because the $\mathrm{z}$-statistic value of 0.145 is less than the z-table value of 1.960. According to Mandala and Widodo (2016), the insignificant affect occurs because the banking NIM value in Indonesia is relatively so similar that the industrial competition is not so competitive in the NIM determination.

The ROA variable is not significant for the efficiency of BPD, or in other words, ROA BPD has no real contribution on the efficiency attainment of BPD, because the $\mathrm{z}$-statistic value of 0.198 is less than the z-table value of 1.960. This finding is in line with Muljawan et al. (2014) who found that ROA has no significant impact on efficiency.

The inflation has significant and negative effects on the efficiency of BPD, because the z-statistic value of -2.389 is greater than the z-table value of -1.960 . If the inflation increases of $1 \%$ and the other variables are considered to be constant, the efficiency of BPD will decrease of $0.064 \%$. It is in accordance with the theory. AdjeiFrimpong et al. (2014) stated that the inflation increase will cause the increase in the nonperforming credit, which will decrease the bank efficiency, because the bank will endure the cost much deeper in managing the non-performing credit. Hassan and Sanchez (2007) also stated that the inflation condition will make the bank operation become inefficient, because the inflation will increase the non-performing credit so that the bank should pay the extra cost to manage the non-performing credit. This finding is in line with the result of research conducted by Hassan and Sanchez (2007), Pancurova and Lyocsa (2013), 
Jurnal Ekonomi Pembangunan: Kajian Masalah Ekonomi dan Pembangunan, 20 (1), 2019, 87-99

Garza-García (2012), which showed that inflation has significant and negative coefficient on the bank efficiency.

The economic growth is not significant for the efficiency of BPD, because the z-statistic value of 0.530 is less than the z-table value of 1.960 . This shows that the PDB increase has no real contribution on the bank efficiency attainment and implies that the banks in Indonesia are not sensitive of the PDB change (Jaelani, 2015). This finding is in line with Pambuko (2016).

The interest rate variable has significant and negative effects on the efficiency of BPD, because the $\mathrm{z}$-statistic value of -2.315 is greater than the z-table of -1.960. If the BI Rate increases of $1 \%$ and the other variables are considered to be constant, the efficiency of BPD will increase of $1.223 \%$. Hassan and Sanchez (2007) stated that the high real interest rate will limit the private credit demand, which will negatively affect the efficiency. Whereas, on one side, the high interest rate will make the costumers interested to save their funds in the bank to find the exact profit, while on the other side, the credit distribution becomes decreasing.

\subsection{Result of Likelihood Test}

The Likelihood Ratio (LR) test is used to find out whether the independent variables existing in this research have the joint effects on the dependent variables. In this research, the estimation results of CAR, LDR, NPL, NIM, ROA, the inflation, the economic growth, and the interest rate on the efficiency use the conviction level of $95 \%(\alpha=0.05), n=468$ and $k=8$, degree of freedom $(d f)=k=8$ (because $n>100)$, do $=15.507$. Based on the regression result, it finds the value of Unrestricted Log likelihood of 503.131 and the value of Restricted Log likelihood of 488.268. Therefore, the LR value can be calculated using the following formula:

LR

$$
\begin{aligned}
& =2(\mathrm{ULLF}-\mathrm{RLLF}) \\
& =2(507.348-490.263) \\
& =34.168
\end{aligned}
$$

In testing the joint independent variable effects on the dependent variables, the value of Likelihood Ratio can be known and then it is compared with . The value of Likelihood Ratio of 34.168 is greater than the value of of 15.507 , so it can be concluded that the model used refuses , or in other words, the model used has at least one independent variable that significantly affect the dependent variables.

\section{Conclusion}

At the first stage it was found that during the period of 2012Q1-2016Q2 there were 16 BPD having the high efficiency level average, three BPD having the sufficient efficiency level average, four BPD having the moderate efficiency level average, and three BPD having the low efficiency level average. BPD having the low efficiency level might be caused by the un- optimum use of the existing input to maximize the output. During the period of research there were several banks that were consistent with the efficiency value of $100 \%$ those are BPD Bali, BPD Jambi, and BPD West Java and Banten. In 20212Q4 the highest efficiency level average during the period of research is $97 \%$, while in 2013Q3 the lowest efficiency average during the research is $91 \%$.

The second stage testing showed some findings. CAR and LDR have significant and positive effects on the efficiency of BPD. The inflation and the interest rate have significant and negative effects on the efficiency of BPD, while NPL, NIM, ROA, and the economic growth have no effects on the efficiency of BPD

Based on the researchs' results, Bank Pembangunan Daerah (BPD) as an intermediary institution should reduce waste of use of input and maximize the potential capabilities. BPDs' management is expected to maintain BPDs' internal factors and be aware of external factors that affect efficiency. Increasing CAR and optimizing LDR, proved to be able to improve BPDs' efficiency. While an increase in external factors such as interest rates and inflation can reduce efficiency. 


\section{Refference}

Abidin, Z., \& Endri, E. (2010). Kinerja efisiensi teknis bank pembangunan daerah: Pendekatan Data Envelopment Analysis (DEA). Jurnal Akuntansi dan Keuangan, 11(1), 21-29.

Adjei-Frimpong, K., Gan, C., \& Hu, B. (2014). Cost efficiency of Ghana's banking industry: A panel data analysis. The International Journal of Business and Finance Research, 8(2), 69-86.

Akmal, M., \& Saleem, M. (2008). Technical efficiency of the banking sector in Pakistan. SBP Research Bulletin, 4(1), 6180.

Andries, A. M. (2011). The determinants of bank efficiency and productivity growth in the Central and Eastern European banking systems. Eastern European Economics, 49(6), 38-59.

Berger, A. N., \& Mester, L. J. (1997). Inside the black box: What explains differences in the efficiencies of financial institutions?. Journal of banking \& finance, 21(7), 895-947.

Coelli, T., D. Prasada, R., Bettese, G., \& O'Donnell, C. (2005). An Introduction To Efficiency. Massachussets: Kluwer Academic Publishers.

Endri. (2015).Variabel Makroekonomi Dan Efisiensi Perbankan Di Indonesia. Seminar Nasional Ekonomi Manajemen dan Akuntansi Fakultas Ekonomi Universitas Padang, h.73-80.

Garza-García, J. G. (2012). Determinants of bank efficiency in Mexico: a two-stage analysis. Applied Economics Letters, 19(17), 1679-1682.

Hadad, M. D., Santoso, W., Ilyas, D., \& Mardanugraha, E. (2003). Analisis efisiensi industri perbankan Indonesia: Penggunaan metode nonparametrik data envelopment analysis (DEA). Research Paper, 7(5), 1-28.
Hassan, M. K., \& Sanchez, B. (2007). Efficiency determinants and dynamic efficiency changes in Latin American banking industries. Available at SSRN 3263102.

Hosmer, D. W., \& Lemeshow, S. (2000). Applied Logistic Regression. New York: John Wiley \& Sons, Inc.

Jaelani. (2015). Studi Efisiensi Bank Umum Di Indonesia Tahun 2002 - 2013. Desertasi Tidak Dipublikasi, Doktor Ilmu Manajemen,Universitas Pendidikan Indonesia.

Kurnia, A. S. (2004). Mengukur efisiensi intermediasi sebelas bank terbesar indonesia dengan pendekatan Data Envelopment Analysis (DEA). Jurnal Bisnis Strategi, 13(2), 126-140.

Mandala, R. A. M., \& Widodo, W. (2016). Analisis Determinan Efisiensi Perbankan Indonesia Tahun 2010-2014: Pendekatan Data Envelopment Analysis(DEA)Dan StructureConduct-Performance (SCP) (Doctoral dissertation, Fakultas Ekonomika dan Bisnis).

Mason,R.D.,\&Lind,D.A.(1996).Teknik Statistika untuk bisnis dan Ekonomi. Jakarta: Erlangga.

Muljawan, D., Hafidz, J., Astuti, R. I., \& Oktapiani, R. (2014). Faktor-faktor penentu efisiensi perbankan Indonesia serta dampaknya terhadap perhitungan suku bunga kredit. Working Papar of Bank Indonesia, 2.

Pambuko, Z. B. (2016). Determinan Tingkat Efisiensi Perbankan Syariah Di Indonesia: Two Stages Data Envelopment Analysis. Cakrawala: Jurnal Studi Islam, 11(2), 178-194.

Pancurova, D., \& Lyocsa, S. (2013). Determinants of commercial banks' efficiency: evidence from 11 CEE Countries. Finance a Uver, 63(2), 152.

Sufian, F., \& Kamarudin, F. (2016). Determinants 
Avalaible online at http://journals.ums.ac.id, Permalink/DOI: 10.23917/jep.v20i1.5799

Jurnal Ekonomi Pembangunan: Kajian Masalah Ekonomi dan Pembangunan, 20 (1), 2019, 87-99

of efficiency in the Malaysian banking sector: Does bank origins matter?. Intellectual Economics, 10(1), 38-54.

Utami, D., \& Sufian, S. (2011). Analisis Efisiensi Bank Umum Menggunakan Metode NonParametrik Data Envelopment Analysis (DEA) (Periode Tahun 2006-2008) (Doctoral dissertation, Universitas Diponegoro).
Otoritas Jasa Keuangan. Indonesia Banking Statistics (data during the period 20102016). https://www.ojk.go.id/

Bank Indonesia. Indonesia Banking Statistics (data during the period 2010-2016). https://www.bi.go.id/ 